\title{
Development of Multiplication and Division Concept Learning Media to Increase Student's Problem Solving Skill and Learning Interest
}

\author{
1Danuri, ${ }^{2}$ Taufik Muhtarom, ${ }^{3}$ Wahyu Wuri Tri Wulandari, ${ }^{4}$ Padrul Jana \\ 1 Universitas PGRI Yogyakarta, Department of Elementary School Teacher Education/ (0274) 376808 \\ ${ }^{2} \mathrm{PhD}$ Student at National Dong Hwa University, Taiwan \& Junior Lecturer at Universitas PGRI Yogyakarta/ \\ 085743741233 \\ 3 Universitas PGRI Yogyakarta, Department of Elementary School Teacher Education \\ ${ }^{4}$ Department of Mathematics Education, Faculty of teacher training and education, Universitas PGRI, \\ Yogyakarta, Indonesia \\ e-mail: danuri@upy.ac.id
}

\begin{abstract}
This study aims to (1) find out the quality of the learning media of dakon in mathematics subjects in class II-A of Elementary School of Muhammadiyah Ambarbinangun (2) determines the effectiveness of students learning using dakon media. The research method is research and development. The results of this study indicate that 1) the quality of learning media in terms of the review are a) the results of the assessment of media experts scored 65 with excellent criteria. Material experts score 36 with good criteria. b) the results of the student response questionnaire obtained a percentage of 93\% with excellent criteria. 2) the learning process has been effectively reviewed from: a) the average results of student interest in learning by obtaining a percentage of $89 \%$ with outstanding criteria. b) the ability to solve problems, there are differences, as evidenced by the Paired Sample TTest on the value obtained Sig. (2-tailed) $0,000<0.05$. The media of the dakon has proven to be effective in improving problem-solving skills and interest in learning, seen from the average pretest score of 67.95 and the average posttest score of 83.28 .
\end{abstract}

Keywords: Dakon learning media, Learning interest, Problem Solving Ability.

How to Cite: Danuri., Muhtarom, T., \& Jana, P. (2020). Development of Multiplication and Division Concept Learning Media to Increase Student's Problem Solving Skill and Learning Interest. International Journal on Emerging Mathematics Education, 4(1), 1-10. http://dx.doi.org/10.12928/ijeme.v4i1.15764

\section{INTRODUCTION}

Education is the foundation of life. Education is some experience based on a person or group that can understand something that they did not previously understand (Amabarjaya, 2012). That experience occurs because of the interaction between a person or group with their environment. The interaction causes a process of change (learning) in humans. Subsequently, the process of change results in development for the life of a person or group in their environment.

According to (Agus, 2011), there is a development process in the education process. Education is the process of helping students develop optimally: that is, to develop as high as possible, following the potential and value systems they hold in society. Education is not a process of imposing the will of an adult (teacher) on students, but an effort to create conditions that are conducive to children's development, which conditions that make it easier for children to develop themselves optimally. It means that in the process of education, the child actively develops himself, and the teacher actively helps create facilities (facilitating) for optimal development. 
Related to the critical role of teachers in education, teachers must have the ability to attract the attention and concentration of student learning to be able to focus on the learning given and explained. In its implementation, teachers can use their variety of creative, innovative, or educational learning media that can point in students' knowledge. The learning process requires a media place for learning to improve problem-solving skills and interest in learning, gain interactive experiences. Although, in reality, a teacher always faces students who have low motivation, a professional teacher must not lose the will and must be innovative to create a pleasant learning atmosphere.

Emphasized that learning media is an important thing that could be used to channel messages, channel the thoughts, feelings, concerns, and wishes of students that could help the learning process (Asra \& Sumiati, 2009). The learning media also has several benefits, including attracting the attention of students, thus arousing students' interest, motivation, activity, and learning creativity.

Few teachers possess fewer abilities in attracting students' attention and concentration. To be more focused on learning. Besides, the lack of use and development of learning media that can support teaching and learning activities often become a significant problem in learning in schools. Often teachers only explain the material verbally without doing simple practices using instructional media so that it obstructs students' understanding of the material being taught. It is expected that teachers can provide optimal learning by using creative, innovative, and active learning media.

Learning mathematics is a learning process about definitions and concepts so that the detail must be truly understood by students at all levels of education, including the elementary grades. Not a bit makes it difficult for students to grasp abstract mathematical theories so that it results in reduced ability and interest in learning, especially in arithmetic operations.

Based on the previous observations showed that there were some problems in learning mathematics, namely the teacher had not yet developed and utilized learning media for mathematics subjects. It can be seen from the teacher never using instructional media in explaining and or even delivering material. It has an impact on the ability of students and students' interest in learning when the learning process of multiplication and division of mathematics takes place. Therefore it is necessary to develop learning media to overcome these problems. One of the media that can help is 'Dakon's game media. The 'Dakon' game is a traditional game that can improve the ability to count because the 'Dakon' game can help and facilitate students in understanding the concept of mathematical counting while also being able to please students because it contains elements of the game.

From the description above, the researcher developed a learning media on mathematics that includes multiplication and division. Dakon media developed is expected to improve students' problem-solving abilities and learning interests. in the end, make students have a great interest in learning and make it easier in the process of learning mathematics. Based on the limitation of the problems outlined above, the formulation of the problem in this study is 1 . How is the development of 'Dakon' learning media in mathematics in class II-A of Elementary School of Muhammadiyah Ambarbinangun to improve problem-solving skills and interest in learning students' math arithmetic operations? 2. How is the quality of 'Dakon' learning media in mathematics in class II A at Muhammadiyah Ambarbinangun Elementary School? 3. How is the effectiveness of students' learning after using the learning media

IJEME, Vol. 4, No. 1, September 2020, 1-10. 
"DAKPERGI" in Mathematics class II A Elementary School of Muhammadiyah Ambarbinangun?

Based on the background above, the researcher is interested in conducting a research development under the title "Development of DAKPERGI Learning Media To Improve Problem Solving Ability and Interest in Learning in Mathematical Compute Operations in Class II A Elementary School of Muhammadiyah Ambarbinangun."

\section{Literature Review}

\section{Development}

Development is a process or steps to develop a new product or improve existing products, which can be accounted for. These products are not always in the form of objects or hardware such as books, modules, learning aids in the classroom or laboratory (Sudjana \& Rivai, 2008). However, it can also be a software, such as computer programs for data processing, classroom learning, library or laboratory and or models of education, learning, training, guidance, evaluation, management, and others.

In the steps of research and development there are ten research and development implementation strategies that can produce an educational product that can be accounted for: a) research and data collection b) planning, c) development of product drafts d) field trials e) revision of the results of trials research f) field trials g) use of product results from field tests $\mathrm{h}$ ) field implementation tests i) refinement of final products j) dissemination and implementation

\section{Learning Media}

The media comes from the Latin word is a plural form of the word "medium" literally; the word has an intermediary or introduction meaning. However, now the word is used both for the plural. Many experts and organizations provide limits on the understanding of the media, that learning media is a container of messages, the material to be conveyed is learning messages with the goal being achieved is the learning process. Furthermore, the creative use of media will increase the likelihood for students to learn more, keep in mind what they have learned better, and improve their performance in carrying out the skills following their learning objectives.

\section{Mathematics Learning}

Mathematics is one of the fields of study studied by all students from elementary to tertiary levels. Learning mathematics cannot be done partially but requires holistic thinking from various units in mathematics (Ibrahim \& Suparni, 2012). Meanwhile, according to (Ruseffendi \& Dkk, 1991) is the language of the symbol of deductive science that does not receive an inductive proof, the science of orderly patterns and organized structures is not defined. The nature of mathematics, according to (Soedjadi, 2000 ), is the object of abstract objectives, relying on the agreement and deductive thinking patterns (Heruman, 2008).

Thus, it can be concluded that mathematics is an abstract science that is used to convey information or knowledge about shapes, sizes, and spaces for arithmetic to facilitate the mind.

\section{4. 'Dakon'}

Dakon or congklak is a traditional game that uses a longboard with seven basins on each side, and two larger basins in the middle of the left and right end called the granaries (Fad, 2011). Basins on the sides are filled with grains or gravel. Also, there 
are congklak seeds that come from a slightly oval round-shaped sea coral shell or imitations made from plastic in the shape of each basin filled with 12 seeds. Meanwhile, according to (Sulaiman, 2013) 'Dakon' game is a traditional game that can improve the ability to count because the 'Dakon' game can help and facilitate students in understanding the concept of mathematical counting while also being able to please students because it contains elements of the game. Dakon is a traditional strategy game. The dakon uses dakon board and seeds by playing it $14 \times 7$ pieces. The most collected seeds are the winner in the granary player. This game can train the ability to think for players, but now, most people are not interested to play the traditional games like dakon, because many have switched to digital and electronic games that are considered more practical, making traditional things begin to be set aside (Putri \& Chandra, 2018). Usually, the tools used are made of wood or plastic shaped like a boat with a length of about $75 \mathrm{~cm}$ and a width of $15 \mathrm{~cm}$ (Kurniawan, 2017).

\section{Problem Solving Ability}

Problem solving is very important that it becomes a general purpose math teaching math even as his heart. The process of thinking in problem solving strategy requires the ability to organize. It will make student to think critically, logically, creatively indispensable in dealing with the development of society (Istikomah \& Jana, 2019). Problem solving is the ability and knowledge that is central to teaching and learning activities in mathematics (Jana \& Fahmawati, 2020; Usman, 2014). According to the Big Indonesian Dictionary, understanding comes from the word understanding, which means the process, method, act of understanding or understanding (Fitriani \& Maulana, 2016). It can be concluded that the ability of mathematical understanding is the ability of a person to remember, understand, explain, and apply mathematical concepts to solve problems in everyday life

\section{Interest in Learning}

Interest in learning can be interpreted as an interest in an object, which then encourages individuals to learn and pursue everything related to the learning interest. Learning interest is obtained through the existence of a learning process developed through the process of assessing an object, which then produces an assessment. Specific assessment of objects that cause a person's learning interest. The assessment of objects obtained through the learning process is what then results in a decision to recognize the attraction or disinterest of a person against the object he faces. Learning interest is the result of experience or learning process (Hurlock, 2003).

\section{RESEARCH METHOD}

This research method is research and development (R\&D). Research and development methods are research methods used to produce specific products and test the effectiveness of these products (Anggraini, Warniasih, \& Jana, 2019; Sugiyono, 2011). This study uses a development model, according to Borg \& Galt. The research development steps according to Sugiyono are (1) Potential and problems, (2) Data collection, (3) Design Product, (4) Validation, (5) Design Revision, (6) Product Trial, (7) Revision Product, (8) Testing Usage, (9) Revision Product, (10) Mass production. The test subjects in this study were students of class II A and II B of Elementary School of Muhammadiyah Ambarbinangun with experimental designs before \& after. The flow chart in the research process is shown in Figure 1 below (Sugiyono, 2011).

IJEME, Vol. 4, No. 1, September 2020, 1-10. 


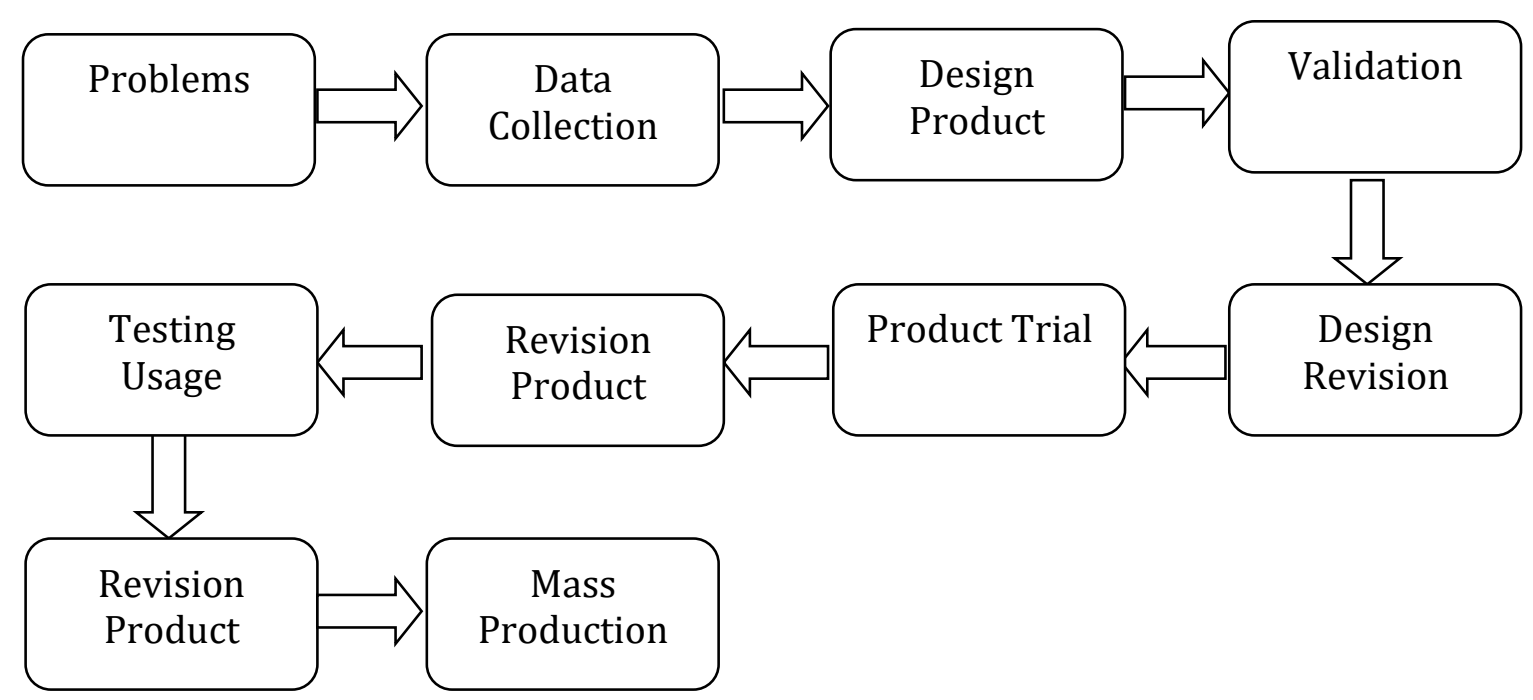

Figure 1. Development steps.

The first stage is to explore the problems at Muhammadiyah Elementary School Ambarbinangun regarding the needs of learning media. Data collection is done by identifying curriculum, material, and learning media needs. After the information is collected, the development of Dakon learning media is carried out. Dakon media at this stage is the initial product is still a lot of revision. The next stage is the Dakon media design validation that has been made by presenting experts in the field of instructional media. Then an evaluation was made to adjust input from the instructor media. After the revision is complete, a product trial is conducted on a small scale and a revision (if any) is then carried out on a trial run on a large scale.

Data collection techniques, namely using tests and questionnaires. The existing instruments are media expert instruments, material expert instruments, student responses, interest in learning, and test solving abilities. After learning the 'Dakon' learning media is validated by experts (media and material), then the 'Dakon' media is delivered to students in the teaching and learning process, namely by implementing the 'Dakon' media on multiplication and division material. Product trials were conducted on 15 students of Class II B of Elementary School of Muhammadiyah Ambarbinangun, and trial of use was conducted on research subjects in class II-A of Elementary School of Muhammadiyah Ambarbinangun.

Data analysis techniques used in this study are descriptive qualitative analysis techniques and quantitative analysis. Data analysis was performed to see the value of each aspect in the questionnaire. Data analyzed included media quality data from media experts and material experts, responses provided by students and teachers, learning interest questionnaires, and problem-solving ability tests to see the effectiveness of the media tested by Paired Samples T-Test. The questionnaire contains responses about the product being developed. Data analysis techniques will be described and explained one by one as follows:

Media Quality

This quantitative data was obtained from scores obtained in the student response questionnaire and the teacher's response questionnaire. Student response data can be analyzed using the following formula:

Percentage value $=($ Earnings score $) /($ Maximum score $) \times 100 \%$ 
In this study, to determine the effectiveness of the media, it is necessary to do a Paired Samples T-Test on the average value of pretest and postest learning motivation. This aim is to determine the significance of the improvement of problem-solving abilities, and According to Sunarti and Rahmawti (2014: 129), if the results of the data are more of the significance of $5 \%(0.05)$ or $t$-count $>t$-table, it can be concluded that the results are a significant increase.

\section{RESULTS AND DISCUSSION}

The development of the learning media for 'Dakon' on multiplication and distribution material is carried out based on analyzing the needs data obtained through gathering information about the learning conditions on the material in grade II of Elementary School Muhammadiyah Ambarbinangun. 'Dakon' media is a learning media that is made from the development of multiplication and distribution materials in the 2013 Thematic Integrated Thematic Book Class II semester 1 Theme 2, namely Playing in My Environment. Media Flannel Board was made to increase interest in learning and problem-solving skills in mathematics class II at the Elementary School of Muhammadiyah Ambarbinangun. The media is made of plywood coated in flannel cloth with a size of $75 \mathrm{~cm} \times 60 \mathrm{~cm}$. This 'Dakon' media design is made as attractive as possible so that students are more interested in paying attention to the teacher and can increase student learning and problem-solving abilities.

below is a verification of the use of Dakon media in the teaching and learning process in the classroom in improving the ability to solve problems and interest in learning mathematics.

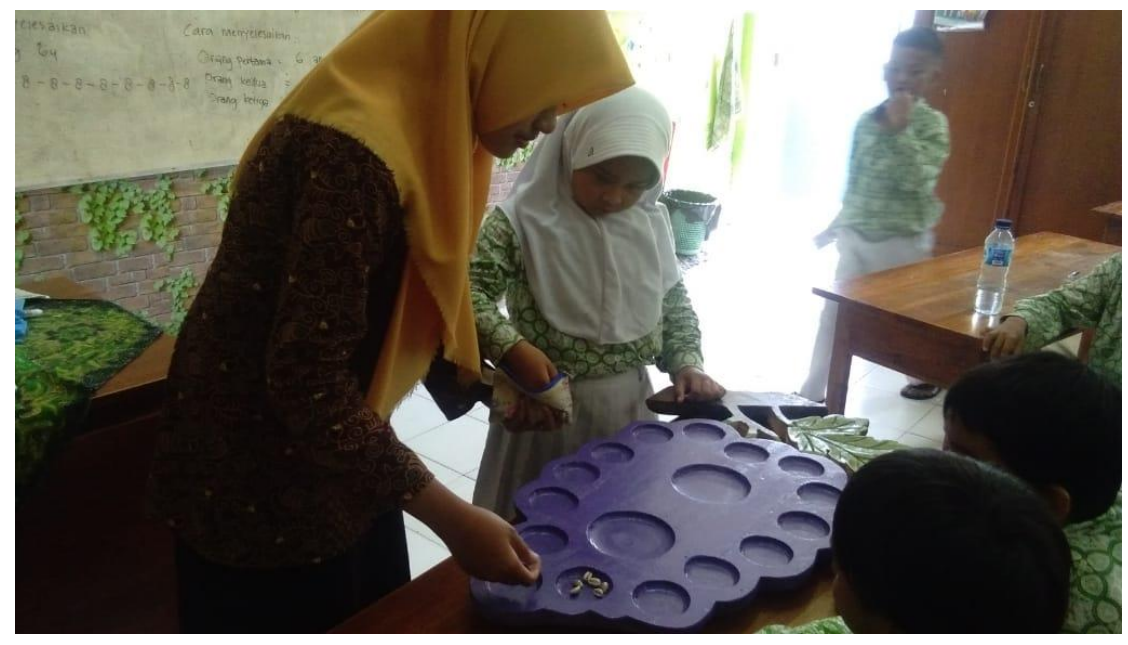

Figure 2. The use of Dakon media in the learning process in class.

The result of media validation obtained a score of 65 by having the excellent quality or criteria and having an A. Results of Expert Material Assessment scores obtained from the trial use questionnaire resulted in a percentage of 93\% for the "yes" assessment and $0.7 \%$ for the "no" assessment. From this score, it can be concluded that the highest percentage of scores is a "yes" rating or a positive response. Based on the assessment guidelines used, a score of $93 \%$ includes intervals of $85 \%$ - 100\% with excellent information. 
Table 1. Results of Expert Material Validation.

\begin{tabular}{lll}
\hline & Aspect Reviewed & Achievement Score \\
\hline $1 \quad$ Curriculum & 8 \\
2 & Material Appropriateness & 8 \\
$3 \quad$ Content & 20 \\
Total of score & 36 \\
Criteria & Good \\
Category & B \\
\hline
\end{tabular}

\section{CONCLUSION}

The results of the 'Dakon' Learning Media development research can be concluded as follows: 1 . The process of developing the media for teaching Mathematics class II is following Sugiyono's research and development steps. The steps are consist of 10 research steps namely: (1) potential problems, (2) data collection, (3) product design, (4) design validation, (5) design revisions, (6) product trials, (7) product revisions, (8) usage trials, (9) product revisions, and (10) final product results. In the final step, the researchers turned it into the final product, because this research did not do mass production. The media developed contains learning material about multiplication and division. 2.

The quality of 'Dakon' learning media products can be declared good and appropriate for use in the learning process. Because the instructional media can be developed further, the product assessment is carried out by the material expert validator and the media expert, the score obtained by the material expert is 36 with a "B" value category in which this value is included in good criteria, so it does not make revisions. While the acquisition score from the validation of media experts is 65 with the category "A" which is included in the criteria very well and has no revision and there are also results of student responses conducted at Elementary School of Muhammadiyah Ambarbinangun with limited product trials conducted in class II B, with 15 students, showed a positive response of $91 \%$ and a negative response of $9 \%$. Based on the assessment guidelines used $91 \%$ score with very good information. Furthermore, the results of the responses of students testing the use of products conducted in class II A with a total of 31 students, showed a positive response of $93 \%$ and a negative response of $7 \%$. With very good information, so the product can improve the ability of interest in learning and the ability to solve mathematical problems for students. 3. The Learning Process is said to be effective, it can be seen from the results of the questionnaire interest in learning towards the media of the score getting a score of 412 with a percentage of the overall value obtained which is $89 \%$ with a value of A (very good) while the results of the pretest score that is getting an average value of 67.95 and posttest score 93.28. Based on the comparison of the pretest and posttest values, it can be seen that there is an increase in interest in learning and problem-solving abilities before and after using the media of 'Dakon.' After being given an action using the media, the 'Dakon' is obtained Sig. ( 2 tailed) 0,000 which indicates that the data is smaller than 0.05 or $(0,000<0.05)$. Because of the value of Sig. $=0,000<0.05$ then $\mathrm{H} 0$ is rejected and $\mathrm{H} 1$ is accepted, it means that learning using the media of 'Dakon' is effectively used when viewed from the results of interest in learning and problem-solving skills in Mathematics. 


\section{REFERENCES}

Agus, T. (2011). Pendidikan Anak di SD. Jakarta: Universitas Terbuka.

Amabarjaya, B. S. (2012). Psikologi Pendidikan \& pengajaran teori \& praktik. Jakarta: CAPS.

Anggraini, C. M., Warniasih, K., \& Jana, P. (2019). Development of Student Work Sheets Based on Contextual Learning to Facilitate Mathematic Concept Understanding Skill of Junior High School Student 7th Grade. Formatif: Jurnal Ilmiah Pendidikan MIPA. https://doi.org/10.30998/formatif.v9i1.2773

Asra, \& Sumiati. (2009). Metode Pembelajaran. Bandung, Jawa Barat, Indonesia: CV. Wacana Prima.

Fad, A. (2011). Kumpulan Permainan Anak Tradisional Indonesia. Jakarta: Cerdas Interaktif.

Fitriani, K., \& Maulana. (2016). Meningkatkan Kemampuan Pemahaman Dan Pemecahan Masalah Matematis Siswa Sd Kelas V Melalui Pendekatan Matematika Realistik. Mimbar Sekolah Dasar, 3(1), 40-52. https://doi.org/10.17509/mimbar-sd.v3i1.2355

Heruman. (2008). Model Pembelajaran Matematika. Bandung, Jawa Barat, Indonesia: PT Remaja Rosdakarya.

Hurlock, E. B. (2003). Perkembangan Anak jilid 2. Jakarta: Erlangga.

Ibrahim, \& Suparni. (2012). Pembelajaran Matematika Teori dan Aplikasinya. Yogyakarta: SUKA-Press UIN Sunan Kalijaga.

Istikomah, D. A., \& Jana, P. (2019). Mathematical Prolem Solving Ability in Apos Modified Learning Model ( M-APOS ). Journal of Physics: Conference Series, 1254(2019), 1-6. https://doi.org/10.1088/1742-6596/1254/1/012071

Jana, P., \& Fahmawati, A. A. N. (2020). Model Discovery Learning untuk Meningkatkan Kemampuan Pemecahan Masalah. Aksioma Jurnal Pendidikan Matematika FKIP Univ. Muhammadiyah Metro, 9(1), 213-220. https://doi.org/http://dx.doi.org/10.24127/ajpm.v9i1.2157

Kurniawan, I. (2017). Model Pembelajaran Kooperatif Melalui Permainan Dakon Termodifikasi untuk Meningkatkan Motivasi Belajar Siswa. JURNAL PENELITIAN PENDIDIKAN MATEMATIKA, 1(2), 148-155. https://doi.org/https://doi.org/10.32502/jp2m.v1i2.1489

Putri, T. A. S. D., \& Chandra, J. C. (2018). Penerapan Algoritma Minimax dalam Permainan Dakon Pada SD Negeri 04 Pondok Ranji. Skanika, 1(2), 836-841. Retrieved from http://jom.fti.budiluhur.ac.id/index.php/SKANIKA/article/view/298

Ruseffendi, E. T., \& Dkk. (1991). Pendidikan Matematika 3. Jakarta: Depdikbud.

Soedjadi. (2000). Kiat Pendidikan Matematika di Indonesia. Jakarta: Direktorat Jendral Pendidikan Tinggi Departemen Pendidikan Nasional.

Sudjana, N., \& Rivai, A. (2008). Media Pengajaran. Bandung, Jawa Barat, Indonesia: Sinar Baru Algensindo Bandung.

Sugiyono. (2011). Metode Penelitian Kuantitatif, Kualitatif dan R\&D. Bandung, Jawa Barat, Indonesia: Alfabeta.

Sulaiman, A. (2013). Penerapan Media Permainan Dakon Dalam Peningkatan Hasil Belajar Berhitung Siswa Kelas 1 SD Al-Amin Surabaya. Jurnal Penelitian Pendidikan Guru Sekolah Dasar, 1(1), 1-7. Retrieved from https://jurnalmahasiswa.unesa.ac.id/index.php/jurnal-penelitian- 
pgsd/article/view/2031

Usman. (2014). Aktivitas Metakognisi Mahasiswa Calon Guru Matematika dalam Pemecahan Masalah Terbuka. Didaktik Matematika, 1(2), 21-29. 
